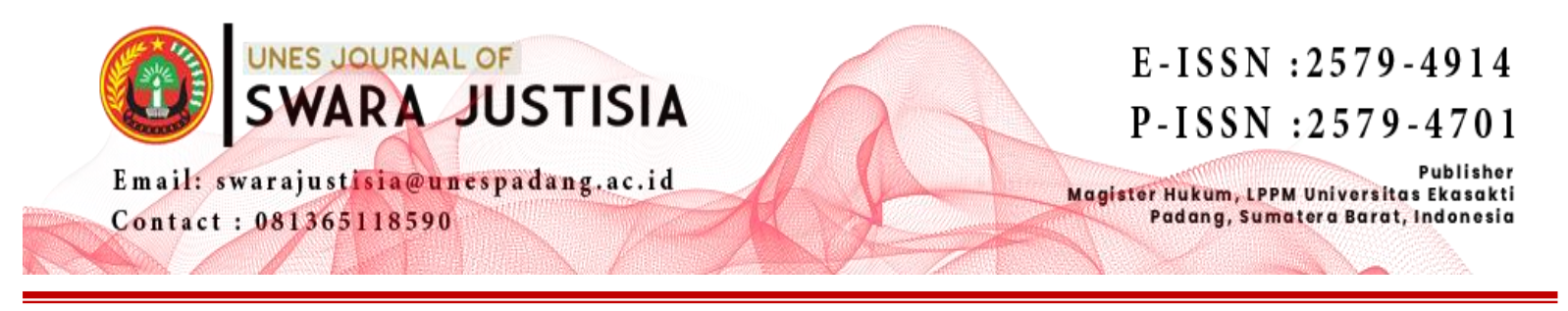

\title{
PERLINDUNGAN HUKUM PEMILIK MEREK TERDAFTAR BAGI USAHA MIKRO KECIL DAN MENENGAH (UMKM) DI SUMATERA BARAT
}

\author{
Nursyahid \\ Program Magister Ilmu Hukum Universitas Ekasakti, Padang Indonesia \\ Email: nursyahid.com
}

\begin{abstract}
Protection of Intellectual Property Rights (IPR) is an acknowledgment or reward given by the state to someone for their intellectual work. Protection of brands is basically part of legal protection against fraudulent competition, which is a violation of the law in the trade sector. To protect the rights to a mark, the owner of the mark must register his mark according to the applicable regulations, namely Law Number 20 of 2016 concerning Marks and Geographical Indications. However, in practice it is not as expected because Micro, Small and Medium Enterprises (MSMEs) in West Sumatra Province have not realized how important the registration of a trademark or service is, and what is obtained from the registration of the trademark. This can be seen that the registration of trademarks has not been optimal for business actors to ask for their protection through the Office of Cooperatives and SMEs of West Sumatra Province to the Regional Office of the Ministry of Law and Human Rights of West Sumatra. That the Legal Protection of Registered Marks for MSMEs in West Sumatra is only given by the State to the owner of the mark registered in the General Register of Marks for a certain period of time using the mark himself or giving permission to a person or several people together or a legal entity to use it, so that the mark is not imitated by others, and as authentic evidence when there is a violation of the right to the mark as well as supervision for law enforcement officers. Meanwhile, the obstacles faced by MSMEs as registered trademark owners in obtaining legal protection are the length of time for completion of trademark certificates by the Director General of IP, the cost of trademark registration is expensive/high, and the SIMPAKI network for trademark registration is often constrained and the lack of socialization about the benefits of trademark registration for SMEs.
\end{abstract}

Keywords: Legal Protection, Registered Mark

\begin{abstract}
ABSTRAK
Perlindungan Hak Kekayaan Intelektual (HKI) adalah merupakan pengakuan atau imbalan yang diberikan oleh negara kepada seseorang atas hasil karya intelektualnya. Perlindungan atas merek pada dasarnya merupakan bagian dari perlindungan hukum terhadap persaingan curang adalah perbuatan melanggar hukum di bidang perdagangan. Untuk melindungi hak atas merek, maka pemelik merek harus mendaftarkan mereknya menurut peraturan yang berlaku, yaitu Undang-undang Nomor 20 Tahun 2016 tentang Merek dan Indikasi Geografis. Namun dalam prakteknya tidak seperti yang diharapkan karena pelaku Usaha Mikro, Kecil
\end{abstract}


dan Menengah (UMKM) di Provinsi Sumatera Barat belum menyadari betapa pentingnya pendaftaran merek dagang atau jasa, dan yang didapat dari pendaftaran merek dagang tersebut. Hal ini dapat dilihat belum optimalnya pendaftaran merek untuk dimintakan perlindungannya oleh pelaku usaha melalui Kantor Dinas Koperasi dan UMKM Provinsi Sumatera Barat kepada Kantor Wilayah Kementerian Hukum dan HAM Sumatera Barat. Bahwa Perlindungan Hukum Merek Terdaftar Bagi UMKM di Sumatera Barat adalah hanya diberikan Negara kepada pemilik merek yang terdaftar dalam Daftar Umum Merek untuk jangka waktu tertentu menggunakan sendiri merek tersebut atau memberi izin kepada seseorang atau beberapa orang secara bersama-sama atau badan hukum untuk menggunakannya, agar merek tersebut tidak ditiru oleh orang lain, dan sebagai alat bukti otentik bila terjadi pelanggaran hak atas merek serta sebagai pengawasan bagi aparat penegak hukum. Sedangkan kendala yang dihadapi UMKM sebagai pemilik merek terdaftar dalam memperoleh perlindungan hukum adalah lamanya waktu penyelesaian sertifikat merek oleh Dirjen KI, biaya pendaftaran merek mahal/tinggi, dan jaringan SIMPAKI untuk pendaftaran merek sering terkendala serta kurangnya sosialisasi tentang manfaat pendaftaran merek bagi UMKM.

Kata Kunci: Perlindungan Hukum, Merek Terdaftar

\section{PENDAHULUAN}

Kemajuan telekomunikasi telah mendorong arus globalisasi di bidang industri dan perdagangan. Hal tersebut menjadikan dunia sebagai suatu pasar tunggal bersama dalam era perdagangan bebas dunia, Indonesia sebagai negara berkembang harus mampu mengambil langkah-langkah yang tepat untuk dapat mengantisipasi segala perubahan dan perkembangan serta kecenderungan global tersebut sehingga tujuan nasional dapat tercapai. Kekayaan Intelektual (KI) sebagai bagian dari sistem hukum sangat erat kaitannya dengan industri, perdagangan dan investasi, singkatnya dunia usaha. Sementara pendapat mengatakan, bahwa hukum itu berkembang dengan mengikuti tahap-tahap perkembangan masyarakat. ${ }^{1}$

Dalam dunia perdagangan khususnya dalam lalu lintas perdagangan barang dan jasa "Merek"2 memegang peranan yang cukup penting. Peran merek disamping sebagai suatu tanda yang dikenal oleh konsumen juga dapat menjadi jaminan bagi kualitas barang/jasa apabila konsumen sudah terbiasa untuk menggunakan merek tertentu. Seiring dengan semakin berkembangnya dunia perdagangan di Indonesia, maka kebutuhan akan identitas suatu produk semakin meningkat serta semakin beragam. Hal ini bisa kita lihat salah satunya dengan semakin banyaknya berbagai merek $^{3}$, baik merek barang maupun merek jasa.

Dalam upaya inilah Indonesia harus berjuang, selain meningkatkan produk barang dan jasa yang unggul juga meningkatkan upaya perlindungan terhadap barang dan jasa produksi dalam negeri melalui peraturan perundang-undangan mengenai KI, khususnya tentang merek yang berperan penting sekaligus memerlukan pranata hukum yang lebih

1 Satjipto Rahardjo, Hukum dan Masyarakat, Angkasa, Bandung, 1980, hlm.102.

${ }^{2}$ Gunawan Suryomurcito, Pokok-pokok Hukum Merek dan Persaingan Curang: Makalah Disampaikan pada Training Dasar mengenai Hak Kekayaan Intelektual bagi Kalangan Universitas, Tangerang, tanggal 5-23 Desember 2005

${ }^{3}$ Kompilasi Peraturan Perundang-undangan Kekayaan, Direktorat Jenderal Kekayaan Intelektual Kementerian Hukum dan Hak Asasi Manusia RI, Jakarta, 2016, hlm. 262 
memadai. Berdasarkan pertimbangan tersebut sejalan dengan perjanjian-perjanjian internasional yang telah diratifikasi Indonesia seperti keluarnya UU Nomor 20 Tahun 2016 tentang Merek dan Indikasi Geografis serta Peraturan Pemerintah RI Nomor 23 Tahun 1993 Tentang Tata Cara Permintaan Pendaftaran Merek.

Merek yang kadang hanya berupa suatu kata atau dapat berfungsi menunjukkan asal serta kualitas suatu produk sehinggga banyak orang ingin meniru merek yang sudah mempunyai nama atau mendompleng ketenaran merek tersebut dengan cara membuat merek yang mirip atau menyerupainya untuk kelas atau jenis produk yang sama. Suatu merek diharuskan mempunyai unsur pembeda karena pendaftaran suatu merek terkait dengan pemberian monopoli suatu nama atau simbol (atau dalam bentuk lain). Para pejabat hukum di seluruh dunia enggan memberikan hak eksklusif atau suatu merek kepada para pedagang. Keengganan ini disebabkan pemberian hak eksklusif tersebut akan menghalangi orang lain untuk menggunakan merek tersebut. Oleh karenanya suatu merek harus dapat membedakan barang dan jasa si pelaku dagang tersebut dari barang atau jasa pelaku dagang lain di bidang yang sama. ${ }^{4}$

Perbuatan meniru merek lain yang sudah terdaftar pada kantor pendaftaran merek, dalam arti sudah mendapat perlindungan hukum dan menggunakannya dalam dunia perdagangan adalah merupakan perbuatan yang oleh UU Nomor 20 Tahun 2016 dikategorikan sebagai tindak pidana di bidang merek.

Perlindungan KI adalah merupakan pengakuan atau imbalan yang diberikan oleh negara kepada seseorang atas hasil karya intelektualnya. Bambang Kesowo mendefinisikan HKI sebagaimana dikutip oleh Rachmadi Usman mengatakan kepemilikian terhadap karyakarya yang lahir karena adanya kemampuan intelektualitas manusia dalam bidang ilmu pengetahuan dan teknologi dimana karya-karya tersebut merupakan kebendaan tidak berwujud yang merupakan hasil kemampuan melalui daya cipta, rasa, karsa dan karyanya. ${ }^{5}$

Ketentuan pidana di bidang merek ini merupakan hal sangat penting bagi pemilik merek karena dengan demikian pemilik merek mendapatkan perlindungan hukum. Untuk mendapatkan perlindungan hukum pemilik merek harus mendaftarkan mereknya pada kantor pendaftaran merek. Hanya terhadap merek yang telah terdaftar pada kantor pendaftaran merek yang mendapatkan perlindungan hukum. Maksud terdaftar di sini bahwa merek tersebut sudah terdaftar dalam daftar umum merek dengan diberi nomor register. Oleh karena itu mendaftarkan merek pada Kantor Pendaftaran Merek harus menyebutkan jenis barang yang dimintakan pendaftarannya adalah merek dagang. Demikian pula terhadap permintaan pendaftaran merek jasa, harus menyebutkan jenis jasa yang dimintakan perlindungan. Tanpa menyebut jenis barang atau jenis jasa pada permintaan pendaftaran merek, maka permintaan pendaftaran merek tersebut tidak dapat diterima oleh Kantor Pendaftaran Merek.

Perlindungan atas merek pada dasarnya merupakan bagian dari perlindungan hukum terhadap persaingan curang adalah perbuatan melanggar hukum di bidang perdagangan, dalam hal ini di Provinsi Sumatera Barat untuk melindungi atas merek, supaya pemilik tidak diganggu gugat oleh hubungan baiknya dengan para konsumen, yang telah dibina oleh pasar

${ }^{4}$ Intellectual Property Rights (Elementary), Buku Panduan Training Tingkat Dasar, IASTP Jakarta, 2002, hlm.194

${ }^{5}$ Rachmadi Usman, Hukum Hak Atas Kekayaan Intelektual, Perlindungan dan Dimensi Hukumnya di Indonesia, Alumni, Bandung, 2003, hlm. 2. 
melalui penggunaan suatu merek tertentu, serta harapan wajar untuk memperoleh langganan tetap yang menunjukan bahwa pemilik merek tersebut adalah dari produsen dari barang yang bersangkutan, maka pemelik merek harus mendaftarkan menurut peraturan yang berlaku.

Walaupun pengaturan tentang merek sudah secara tegas diatur oleh negara dalam suatu peraturan perundang-undangan yaitu Undang-undang Nomor 20 Tahun 2016 tentang Merek dan Indikasi Geografis, akan tetapi dalam prakteknya tidak seperti yang diharapkan karena pengusaha khususnya di Provinsi Sumatera Barat belum menyadari betapa pentingnya pendaftaran merek dagang atau jasa dan yang didapat dari pendaftaran merek dagang tersebut. Hal ini dapat dilihat dari merek yang dimintakan perlindungannya di Provinsi Sumatera Barat oleh pelaku usaha melalui Kantor Usaha Mikro, Kecil dan Menengah (UMKM) Provinsi Sumatera Barat dan Koperindag Provinsi Sumatera Barat kepada Kantor Wilayah Kementerian Hukum dan HAM Sumatera Barat selama tiga tahun terakhir yaitu pada tahun 2017 sampai dengan tahun 2019.

Berdasarkan isu-isu hukum di atas, maka perlu dilakukan penelitian tentang :

1. Bagaimanakah perlindungan hukum pemilik merek terdaftar bagi UMKM di Sumatera Barat?

2. Apakah kendala-kendala yang dihadapi UMKM sebagai pemilik merek terdaftar dalam memperoleh perlindungan hukum ?

\section{METODE PENELITIAN}

Pendekatan yang digunakan dalam penelitian adalah pendekatan yuridis normatif sebagai pendekatan utama dan didukung dengan pendekatan yuridis empiris. Penelitian hukum normatif adalah merupakan penelitian hukum yang mengkaji hukum tertulis dari berbagai aspek, yaitu aspek teori, sejarah, filosofi, perbandingan, struktur dan komposisi, lingkup dan dan materi, konsistensi, penjelasan umum dan pasal demi pasal formalitas dan kekuatan mengikat suatu undang-undang, serta bahasa hukum yang digunakan, tetapi tidak mengkaji aspek terapan dan implementasinya. Penelitian hukum normatif sering juga disebut penelitian hukum dogmatik atau penelitian hukum teoritis (dogmatic or theoretieal law research. ${ }^{6}$

Sedangkan pendekatan yuridis empiris adalah metode penelitian yang dilakukan untuk mendapatkan data primer dan menemukan kebenaran dengan menggunakan metode berpikir induktif dan kriterium kebenaran koresponden serta fakta yang digunakan untuk melakukan proses induksi dan pengujian kebenaran secara koresponden adalah fakta yang mutakhir ${ }^{7}$.

\section{HASIL DAN PEMBAHASAN}

\section{A. Perlindungan Hukum Pemilik Merek Terdaftar Bagi UMKM di Sumatera Barat}

Kekayaan Intelektual (KI) adalah sebuah aset berharga yang dapat memajukan perekonomian suatu bangsa. Direktorat Jenderal Kekayaan Intelektual Kementerian Hukum dan Hak Asasi Manusia sebagai lembaga tunggal yang menangani pendaftaran dan perlindungan kekayaan intelektual. Untuk melaksanakan pendaftaran KI tersebut

\footnotetext{
${ }^{6}$ Abdul Kadir Muhamad, Hukum dan Penelitian Hukum, Citra Aditya Bakti, Bandung, 2004, hlm.101

7 Soerjono Soekanto dan dan Sri Mamudji, Penelitian Hukum Normatif, suatu Tinjauan Singkat, Cetakan IV, PT. Raja Grafindo Persada, Jakarta,1995, hlm. 14
} 
agar ada perlindungan hukumnya diatur oleh Undang-undang Nomor 20 Tahun 2016 Tentang Merek dan Indikasi Geografis. Selanjutnya seiring dengan semakin berkembangnya dunia perdagangan di Indonesia, maka kebutuhan akan identitas suatu produk semakin meningkat serta semakin beragam. Hal ini bisa dilihat salah satunya dengan semakin banyaknya berbagai merek barang maupun merek jasa.

Adapun Merek adalah tanda yang dapat ditampilkan secara grafis berupa gambar, logo, nama, kata, huruf, angka, susunan warna, dalam bentuk 2 (dua) dimensi dan/atau 3 (tiga) dimensi, suara, hologram, atau kombinasi dari 2 (dua) atau lebih unsur tersebut untuk membedakan barang dan/atau jasa yang diproduksi oleh orang atau badan hukum dalam kegiatan perdagagan barang dan/atau jasa (Pasal 1 angka 1 Undangundang Nomor 20 Tahun 2016 Tentang Merek dan Indikasi Geografis). Dimana suatu merek baru mendapatkan perlindungan harus terlebih dahulu melakukan pendaftaran pada Direktur Jenderal Hak Kekayaan Intelektual Kementerian Hukum dan Hak Asasi Manusia RI dan Kantor Wilayah Kementerian Hukum dan Hak Asasi Manusia Sumatera Barat.

Perlindungan hukum menurut Fitzgerald sebagaimana dikutip Satjipto Raharjo awal mula dari munculnya teori perlindungan hukum bersumber dari teori hukum alam atau aliran hukum alam, menyebutkan bahwa hukum itu bersumber dari Tuhan yang bersifat universal dan abadi, serta antara hukum dan moral tidak boleh dipisahkan, bahwa hukum dan moral adalah cerminan dan aturan secara internal dan eksternal dari kehidupan manusia yang diwujudkan melalui hukum dan moral. ${ }^{8}$ Kemudian John Locke menyatakan bahwa hak atas milik pribadi bermula dari kerja manusia dan dengan kerja inilah manusia memperbaiki dunia ini demi kehidupan yang layak tidak hanya untuk dirinya melainkan juga untuk orang lain. ${ }^{9}$

Selanjutnya menurut Kelsen, hukum adalah sebuah sistem norma. Norma adalah pernyataan yang menekankan aspek "seharusnya" atau das sollen, dengan menyertakan beberapa peraturan tentang apa yang harus dilakukan. Norma-norma adalah produk dan aksi manusia yang deliberatif. Undang-Undang yang berisi aturan-aturan yang bersifat umum menjadi pedoman bagi individu bertingkah laku dalam bermasyarakat, baik dalam hubungan dengan sesama individu maupun dalam hubungannya dengan masyarakat. Aturan-aturan itu menjadi batasan bagi masyarakat dalam membebani atau melakukan tindakan terhadap individu. Adanya aturan itu dan pelaksanaan aturan tersebut menimbulkan kepastian hukum. ${ }^{10}$ Kepastian hukum itu diwujudkan oleh hukum dengan sifatnya yang hanya membuat suatu aturan hukum yang bersifat umum. Sifat umum dari aturan-aturan hukum membuktikan bahwa hukum tidak bertujuan untuk mewujudkan keadilan atau kemanfaatan, melainkan semata-mata untuk kepastian. ${ }^{11}$

Perlindungan hanya diberikan kepada merek terdaftar saja, karena menurut Pasal 35 UU Nomor 20 Tahun 2016, hak atas merek adalah hak yang diberikan Negara kepada

\footnotetext{
${ }^{8}$ Satjipto Raharjo, Ilmu Hukum, PT. Citra Aditya Bakti, Bandung, 2000, hlm. 53

${ }^{9}$ H.D. Effendy Hasibuan, Perlindungan Merek (Studi Mengenai Putusan Pengadilan Indonesia Amerika Serikat), Fakultas Hukum Universitas Indonesia, Jakarta, 2003, hlm. 35

10 Peter Mahmud Marzuki, Pengantar Ilmu Hukum, Kencana, Jakarta, 2008, hlm.158

${ }^{11}$ Achmad Ali, Menguak Tabir Hukum (Suatu Kajian Filosofis dan Sosiologis), Toko Gunung Agung, Jakarta, 2002, hlm.82-83
} 
pemilik merek yang terdaftar dalam Daftar Umum Merek untuk jangka waktu tertentu menggunakan sendiri merek tersebut atau memberi izin kepada seseorang atau beberapa orang secara bersama-sama atau badan hukum atau menggunakannya.

Menurut Peraturan Menteri Hukum dan Hak Asasi Manusia Nomor 67 Tahun 2016 Tentang Pendaftaran Merek Bab II Syarat dan Tata Cara Permohonan Pendaftaran Hak Kekayaan Intelektual, dalam hal permohonan pendaftaran merek Pasal 3 :

1) Permohonan diajukan dengan mengisi formulir rangkap 2 (dua) dalam bahasa Indonesia oleh Pemohon atau Kuasanya kepada Menteri.

2) Permohonan sebagaimana dimaksud pada ayat (1) paling sedikit memuat:

a. tanggal, bulan, dan tahun Permohonan;

b. nama lengkap, kewarganegaraan, dan alamat Pemohon;

c. nama lengkap dan alamat Kuasa jika Permohonan diajukan melalui Kuasa;

d. nama negara dan tanggal permintaan Merek yang pertama kali dalam hal Permohonan diajukan dengan Hak Prioritas;

e. label Merek;

f. warna jika Merek yang dimohonkan pendaftarannya menggunakan unsur warna; dan

g. kelas barang dan/atau kelas jasa serta uraian jenis barang dan/atau jenis jasa.

3) Dalam mengajukan Permohonan sebagaimana dimaksud pada ayat (2) harus melampirkan dokumen:

a. bukti pembayaran biaya permohonan;

b. label Merek sebanyak 3 (tiga) lembar, dengan ukuran paling kecil 2 x $2 \mathrm{~cm}$ (dua kali dua sentimeter) dan paling besar $9 \times 9 \mathrm{~cm}$ (sembilan kali sembilan sentimeter);

c. surat pernyataan kepemilikan Merek;

d. surat kuasa, jika permohonan diajukan melalui Kuasa;

e. bukti prioritas, jika menggunakan Hak Prioritas dan terjemahannya dalam bahasa Indonesia.

4) Dalam hal Merek sebagaimana dimaksud pada ayat (2) huruf e berupa bentuk 3 (tiga) dimensi, label Merek yang dilampirkan dalam bentuk karakteristik dari Merek tersebut yang berupa visual dan deskripsi klaim pelindungan.

5) Dalam hal Merek sebagaimana dimaksud pada ayat (2) huruf e berupa suara, label Merek yang dilampirkan berupa notasi dan rekaman suara.

6) Dalam hal Merek sebagaimana dimaksud pada ayat (2) huruf e berupa suara yang tidak dapat ditampilkan dalam bentuk notasi, label Merek yang dilampirkan dalam bentuk sonogram.

7) Dalam hal Merek sebagaimana dimaksud pada ayat (2) huruf e berupa hologram, label Merek yang dilampirkan berupa tampilan visual dari berbagai sisi.

8) Format formulir Permohonan sebagaimana dimaksud pada ayat (1) ditetapkan oleh Direktur Jenderal.

Selanjutnya dalam Pasal 6 menyebutkan bahwa permohonan sebagaimana dimaksud dalam Pasal 3 dapat dilakukan secara:

a. elektronik; atau

b. non-elektronik. 
Jadi Prosedur Pendaftaran Merek yang dilakukan pada Kantor Wilayah Kementerian Hukum dan Hak Asasi Manusia Sumatera Barat adalah sebagai berikut :

1. Pemohon datang untuk mendaftarkan merek/konsultasi persyaratan;

2. Melengkapi persyaratan yang ditentukan UU untuk pendafataran merek;

3. Menyetor PNBP ke Bank sebesar Rp. 500.000,-/permohonan untuk UMKM dan Rp. 1.800.000,-/permohonan untuk Umum.

Selanjutnya menurut Kepala Sub Bidang Kekayaan Intelektual Kantor Wilayah Kementerian Hukum dan Hak Asasi Manusia Sumatera Barat sesuai dengan peraturan tentang pendaftaran merek UU Nomor 20 Tahun 2016 dan PP Nomor 67 Tahun 2016 yaitu:

1. Pemohon/kuasanya datang ke Kantor Wilayah dan mengisi formulir pendaftaran merek yang telah disediakan diajukan kepada Menteri Hukum dan HAM ;

2. Pemohon mengisi formulir dalam bahasa Indonesia yang memuat :

a) tanggal pengajuan, bulan, dan tahun Permohonan;

b) nama lengkap pemohon;

c) kewarganegaraan;

d) alamat pemohon;

e) nama lengkap surat menyurat;

f) alamat Kuasa jika Permohonan diajukan melalui Kuasa;

g) nama negara dan tanggal permintaan Merek yang pertama kali dalam hal Permohonan diajukan dengan Hak Prioritas;

h) Tipe merek;

i) label Merek;

j) warna jika Merek yang dimohonkan pendaftarannya menggunakan unsur warna;

k) kelas barang dan/atau kelas jasa serta uraian jenis barang dan/atau jenis jasa; dan

1) Tanda tangan pemohon

Setelah selesai pengisian formulir petugas meneliti dan bila belum lengkap maka pemohon dipersilahkan untuk melengkapi terlebih dahulu dan seandainya sudah benar, pemohon ditanya apakah pendaftaran secara manual atau melalui on-line, selanjutnya pemohon dianjurkan untuk membayar Penerimaan Negara Bukan Pajak (PNBP) SIMPAKI melalui Bank dengan memberikan tanda bukti telah membayar PNBP nya.

Berdasarkan hasil penelitian yang penulis lakukan berkaitan dengan perlindungan hukum terhadap pemilik merek terdaftar dalam kegiatan bisnis di Sumatera Barat diperoleh penjelasan sebagai berikut:

"Pada dasarnya pihak Direktur Jenderal KI Kementerian Hukum dan HAM dan Kantor Wilayah Kementerian Hukum dan HAM Sumatera Barat sesuai dengan ketentuan Undang-undang Nomor 20 Tahun 2018 Tentang Merek dan Indikasi Geografis serta syarat dan tata cara permohonan pendaftaran HKI dalam hal pendaftaran merek dengan ketentuan pemohon permohonan diajukan dengan mengisi formulir rangkap 2 (dua) dalam bahasa Indonesia oleh Pemohon atau Kuasanya kepada Menteri”.

Berkaitan dengan pelaksanaan perlindungan hukum terhadap pemilik merek terdaftar dalam kegiatan bisnis di Sumatera Barat diperoleh penjelasan yaitu sebagai 
berikut:

1. Permohonan pendaftaran merek sesuai dengan syarat dan tata cara pendaftaran merek Pasal 3, Permohonan sebagaimana dimaksud pada ayat (1) paling sedikit memuat:

a. tanggal, bulan, dan tahun Permohonan;

b. nama lengkap, kewarganegaraan, dan alamat Pemohon;

c. nama lengkap dan alamat Kuasa jika Permohonan diajukan melalui Kuasa;

d. nama negara dan tanggal permintaan Merek yang pertama kali dalam hal Permohonan diajukan dengan Hak Prioritas;

e. label Merek;

f. warna jika Merek yang dimohonkan pendaftarannya menggunakan unsur warna; dan

g. kelas barang dan/atau kelas jasa serta uraian jenis barang dan/atau jenis jasa.

Dalam melaksanakan kegiatan tersebut Kanwil Kementerian Hukum dan HAM Sumatera Barat telah bekerjasama dengan berbagai instansi antara lain : Kantor Dinas Koperasi dan UMKM Provinsi Sumatera Barat dan Kantor Dinas Koperindag Provinsi Sumatera Barat untuk melaksanakan pendaftaran merek.

2. Dalam mengajukan Permohonan sebagaimana dimaksud pada ayat (2) harus melampirkan dokumen:

a. bukti pembayaran biaya permohonan;

b. label Merek sebanyak 3 (tiga) lembar, dengan ukuran paling kecil 2 × $2 \mathrm{~cm}$ (dua kali dua sentimeter) dan paling besar 9 x $9 \mathrm{~cm}$ (sembilan kali sembilan sentimeter);

c. surat pernyataan kepemilikan Merek;

d. surat kuasa, jika permohonan diajukan melalui Kuasa;

e. bukti prioritas, jika menggunakan Hak Prioritas dan terjemahannya dalam bahasa Indonesia.

Pada kesempatn ini Kantor Wilayah bekerjasama dengan Kantor Dinas Koperasi dan UMKM dan Kantor Dinas Koperindag dan Bank dalam hal penyetoran PNBP.

3. Dalam hal Merek sebagaimana dimaksud pada ayat (2) huruf e berupa bentuk 3 (tiga) dimensi, label Merek yang dilampirkan dalam bentuk karakteristik dari Merek tersebut yang berupa visual dan deskripsi klaim pelindungan.

4. Dalam hal Merek sebagaimana dimaksud pada ayat (2) huruf e berupa suara, label Merek yang dilampirkan berupa notasi dan rekaman suara.

5. Dalam hal Merek sebagaimana dimaksud pada ayat (2) huruf e berupa suara yang tidak dapat ditampilkan dalam bentuk notasi, label Merek yang dilampirkan dalam bentuk sonogram.

6. Dalam hal Merek sebagaimana dimaksud pada ayat (2) huruf e berupa hologram, label Merek yang dilampirkan berupa tampilan visual dari berbagai sisi.

7. Format formulir Permohonan sebagaimana dimaksud pada ayat (1) ditetapkan oleh Direktur Jenderal.

Selanjutnya Kantor Wilayah Kementerian Hukum dan HAM Sumatera Barat meneliti kelengkapan persyaratan pendaftaran merek yang diajukan oleh pemohon seterusnya pemohon menganjurkan kepada pemohon umtuk membayar PNBP melalui bank pemerintah. Setelah ada bukti pembayaran pendaftaran merek, Kanwil Kementerian 
Hukum dan HAM Sumatera Barat langsung mengirimkan berkas pendaftaran merek ke Direktur Jenderal HKI di Kementerian Hukum dan HAM RI melalui on line atau manual sesuai permintaan pemohon.

Temuan penulis terhadap pelaksanaan pendaftaran merek dalam rangka perlindungan merek terdaftar dalam kegiatan bisnis di Sumatera Barat menurut UU Nomor 20 Tahun 2016 Tentang Merek dan Indikasi Geografis dan Peraturan Menteri Hukum dan Hak Asasi Manusia Nomor 67 Tahun 2016 Tentang Pendaftaran Merek Bab II Syarat dan Tata Cara Permohonan Pendaftaran Kekayaan Intelektual, menunjukkan bahwa ketentuan sebagaimana tersebut di atas masih belum sepenuhnya dapat diterapkan dan berjalan dengan baik, karena pemohon pendaftaran belum memahami sepenuhnya tentang ukuran label/logo perusahaan, walaupun sudah diberitahukan dan hal ini disebabkan kurangnya sosialisasi kepada masyarakat sekaligus kurangnya anggaran yang tersedia.

Di samping itu dalam penyelesaian pendaftaran merek oleh Direktur Jenderal KI Kementerian Hukum dan HAM belum sepenuhnya sesuai dengan skema penyelesaiannya lebih kurang satu tahun delapan bulan, bahkan lebih dari tiga tahun belum keluar sertifikat mereknya.

Berdasarkan analisis dan pembahasan sebagaimana yang telah diuraikan di atas, maka dapat dikatakan bahwa Perlindungan Hukum Terhadap Pemilik Merek Terdaftar Dalam Kegiatan Bisnis di Sumatera Barat melalui Kantor Wilayah Kementerian Hukum dan HAM Sumatera Barat telah dilaksanakan sesuai menurut UU Nomor 20 Tahun 2016 Tentang Merek dan Indikasi Geografis dan Peraturan Menteri Hukum dan Hak Asasi Manusia Nomor 67 Tahun 2016 Tentang Pendaftaran Merek Bab II Syarat dan Tata Cara Permohonan Pendaftaran Kekayaan Intelektual, namun belum oftimal karena penyelesaian perlindungan/sertifikat mereknya dikeluarkan oleh Direktur Merek Kementerian Hukum dan HAM RI tidak sesuai dalam aturan tersebut.

\section{B. Kendala-kendala yang dihadapi UMKM sebagai pemilik Merek terdaftar dalam memperoleh perlindungan hukum}

Pada umumnya masalah-masalah yang sering menjadi kendala dalam perlindungan hukum pemilik merek terdaftar antara lain :

1. Sikap lalai dari masyarakat/UMKM untuk mendaftarakan mereknya;

2. Partisipasi masyarakat/UMKM yang masih perlu ditingkatkan, karena masih enggan mendaftarkan merek usahanya;

3. Kerjasama dengan instansi/badan tertentu, baik yang berkaitan langsung maupun tidak langsung masih perlu ditingkatkan;

4. Belum optimalnya berjalan sistem pembayaran PNBP Kekayaan Intelektual (SIMPAKI) dengan baik;

5. Belum optimalnya penyelesaian sertifikat merek;

6. Kurangnya Sosialisasi tentang Manfaat Pendaftaran Merek.

Selanjutnya dijelaskan bahwa, Perlindungan hanya diberikan kepada merek terdaftar saja, karena menurut UU Nomor 20 Tahun 2016, hak atas merek adalah hak yang diberikan Negara kepada pemilik merek yang terdaftar dalam Buku Umum Merek untuk jangka waktu tertentu menggunakan sendiri merek tersebut atau memberi izin 
kepada seseorang atau beberapa orang secara bersama-sama atau badan hukum atau menggunakannya.

Menurut Kepala Sub Bidang Kekayaan Intelektual Kantor Wilayah Kementerian Hukum dan Hak Asasi Manusia Sumatera Barat sesuai dengan peraturan tentang pendaftaran merek UU Nomor 20 Tahun 2016 dan PP Nomor 67 Tahun 2016 yaitu:

1) Pemohon/kuasanya datang ke Kantor Wilayah dan mengisi formulir pendaftaran merek yang telah disediakan diajukan kepada Menteri Hukum dan HAM;

2) Pemohon mengisi formulir dalam bahasa Indonesia yang memuat:

a. tanggal pengajuan, bulan, dan tahun Permohonan;

b. nama lengkap pemohon;

c. kewarganegaraan;

d. alamat pemohon;

e. nama lengkap surat menyurat;

f. alamat Kuasa jika Permohonan diajukan melalui Kuasa;

g. nama negara dan tanggal permintaan Merek yang pertama kali dalam hal Permohonan diajukan dengan Hak Prioritas;

h. Tipe merek;

i. label Merek;

j. warna jika Merek yang dimohonkan pendaftarannya menggunakan unsur warna;

k. kelas barang dan/atau kelas jasa serta uraian jenis barang dan/atau jenis jasa; dan

1. Tanda tangan pemohon

Setelah selesai pengisian formulir petugas meneliti dan bila belum lengkap maka pemohon dipersilahkan untuk melengkapi terlebih dahulu dan seandainya sudah benar, pemohon ditanya apakah pendaftaran secara manual atau melalui on-line, selanjutnya pemohon dianjurkan untuk membayar Penerimaan Negara Bukan Pajak (PNBP) yang dikenal dengan SIMPAKI melalui Bank dengan memberikan tanda bukti telah membayar PNBP nya.

Adapun pembayaran PNBP Direktorat Jenderal KI dilakukan melalui sistem pembayaran berbasis online berdasarkan surat perintah bayar dari Sistem Pembayaran PNBP Kekayaan Intelektual (SIMPAKI) yang memfasilitasi penerbitan kode billing dari SIMPONI (Sistem Informasi PNBP Online) sebagai sarana pembayaran PNBP. Tanda billing dari SIMPONI untuk pendaftaran PNBP Simpaki hanya berlaku 24 jam sejak transaksi atau 1 (satu) hari, seandainya pemohon belum membayar dalam jangka waktu 1 (satu) hari, maka kode billing tidak berlaku lagi, pemohon harus mengambil kembali melalui Simponi. ${ }^{12}$

Berdasarkan hasil penelitian yang penulis lakukan mengenai kendala-kendala yang dihadapi dalam pelaksanaan perlindungan hukum pemilik merek terdaftar bagi UMKM, diperoleh penjelasan bahwa ada 2 (dua) hambatan atau kendala, yaitu pertama kendala internal dan kendala eksternal.

Kendala internal yaitu hambatan yang berasal dari luar instansi Kanwil Kementerian Hukum dan HAM :

${ }^{12}$ Hasil wawancara dengan Kepala Sub Bidang Kekayaan Intelektual Divisi Pelayanan Hukum dan HAM (Muhammad Farhan, S. Sos.), tanggal 31 Januari 2020 
(1) Belum optimalnya berjalan SIMPAKI dengan baik. SIMPAKI adalah Sistem Pembayaran PNBP Kekayaan Intelektual (SIMPAKI) yang memfasilitasi penerbitan kode billing dari SIMPONI (Sistem Informasi PNBP Online) sebagai sarana pembayaran PNBP suatu bentuk pelayanan kepada masyarakat yang diberikan oleh Kementerian Hukum Dan Hak Asasi Manusia Republik Indonesia khususnya Direktorat Jenderal Hak Kekayaan Intelektual dengan menggunakan sistem komputerisasi dalam memproses permohonan pendaftaran merek yang dilakukan secara online, namun proses penyelesaian sertifikat mereknya memakan waktu lama;

(2) Pendaftaran merek sering terkendala oleh jaringan internetnya;

(3) Waktu penyelesaian sertifikat merek oleh Dirjen KI memakan waktu yang lama; dan

(4) Kurangnya sosialisasi tentang manfaat pendaftaran merek.

\section{KESIMPULAN DAN SARAN}

\section{A. Kesimpulan}

1. Perlindungan hukum merek terdaftar bagi UMKM di Sumatera Barat adalah hanya diberikan Negara kepada pemilik merek yang terdaftar dalam Daftar Umum Merek untuk jangka waktu tertentu menggunakan sendiri merek tersebut atau memberi izin kepada seseorang atau beberapa orang secara bersama-sama atau badan hukum untuk menggunakannya, agar merek tersebut tidak ditiru oleh orang lain, dan sebagai alat bukti otentik bila terjadi pelanggaran hak atas merek serta sebagai pengawasan bagi aparat penegak hukum.

2. Kendala-kendala yang dihadapi UMKM sebagai pemilik merek terdaftar dalam memperoleh perlindungan hukum adalah belum dapat segera UMKM menuntut haknya karena belum memiliki sertifikat merek disebabkan lamanya waktu penyelesaian sertifikat merek oleh Dirjen KI, biaya pendaftaran merek mahal/tinggi, dan jaringan SIMPAKI untuk pendaftaran merek sering terkendala serta kurangnya sosialisasi tentang manfaat pendaftaran merek bagi UMKM.

\section{B. Saran}

1. Direktur Jenderal KI Kementerian Hukum dan HAM RI dalam proses penyelesaian sertifikat merek untuk perlindungan hukum merek terdaftar agar mempercepat keluar sertifikat merek sesuai dengan UU No. 20 Tahun 2016 Tentang Merek dan Indikasi Geografis;

2. Untuk kelancaran proses perlindungan hukum merek terdaftar, jaringan internet SIMPAKI agar dioptimalkan;

3. Dalam pengurusan Pendafataran Merek untuk mendapatkan perlindungan hukum bagi UMKM agar biayanya diringankan;

4. Agar Diketur Jenderal KI melalui Kanwil Kemenkumham Sumatera Barat dan Dinas Koperasi dan UMKM Provinsi Sumatera Barat melakukan koordinasi yang berkelanjutan untuk mewujudkan sosialisasi perlindungan hukum merek terdaftar; 


\section{DAFTAR PUSTAKA}

Abdul Kadir Muhamad, Hukum dan Penelitian Hukum, Citra Aditya Bakti, Bandung, 2004.

Achmad Ali, Menguak Tabir Hukum (Suatu Kajian Filosofis dan Sosiologis), Toko Gunung Agung, Jakarta, 2002.

Soerjono Soekanto dan dan Sri Mamudji, Penelitian Hukum Normatif, suatu Tinjauan Singkat, Cetakan IV, PT. Raja Grafindo Persada, Jakarta 1995.

Intellectual Property Rights (Elementary), Buku Panduan Training Tingkat Dasar, IASTP Jakarta, 2002.

Rachmadi Usman, Hukum Hak Atas Kekayaan Intelektual, Perlindungan dan Dimensi Hukumnya di Indonesia, Alumni, Bandung, 2003.

Satjipto Rahardjo, Hukum dan Masyarakat, Angkasa, Bandung, 1980.

Gunawan Suryomurcito, Pokok-pokok Hukum Merek dan Persaingan Curang: Makalah Disampaikan pada Training Dasar mengenai Hak Kekayaan Intelektual bagi Kalangan Universitas, Tangerang, tanggal 5-23 Desember 2005

Kompilasi Peraturan Perundang-undangan Kekayaan, Direktorat Jenderal Kekayaan Intelektual Kementerian Hukum dan Hak Asasi Manusia RI, Jakarta, 2016.

Satjipto Raharjo, Ilmu Hukum, PT. Citra Aditya Bakti, Bandung, 2000

H.D. Effendy Hasibuan, Perlindungan Merek (Studi Mengenai Putusan Pengadilan Indonesia Amerika Serikat), Fakultas Hukum Universitas Indonesia, Jakarta, 2003.

Peter Mahmud Marzuki, Pengantar Ilmu Hukum, Kencana, Jakarta, 2008. 